Ann. Biol. anim. Bioch. Biophys., 1976, 16 (6), 783-790.

\title{
EFFECT OF AMBIENT TEMPERATURE ON FOOD, NITROGEN AND ENERGY INTAKE OF THE FIELD-VOLE, MICROTUS ARVALIS, UNDER DIFFERENT CONDITIONS OF DAYLIGHT RATIO AND FEEDING
}

\author{
Monique CAILLOL and Lise MARTINET \\ with the technical assistance of Régine MonNerie \\ Station centrale de Physiologie animale, \\ Centre national de Recherches zootechniques, I. N. R. A., \\ 78350 Jouy en Josas (France)
}

\section{SUMMARY}

This report studies the effects of temperature $\left(5^{\circ}\right.$ or $22^{\circ} \mathrm{C}$ ), daylight ratio ( $5 \mathrm{~L}: 9 \mathrm{D}$ or ro L : I4 D) or growth stage and harvest time of the alfalfa on field-vole food intake, energy and nitrogen balance.

The amounts of alfalfa eaten and the levels of nitrogen and energy assimilated are always higher at $5^{\circ}$ than at $22^{\circ}$, although conversion ratios are higher at $22^{\circ} \mathrm{C}$.

Daylight ratio effect is evident in one case : long daily daylight increases the proportion of nitrogen metabolized by the animals.

The role of alfalfa growth stage and the season in which it is harvested are not clear because of the storage method used.

Growth rate and sexual maturity in the field-vole depend on several environmental factors, $i$. e. daylight ratio (LECYK, I962, I953; MARTINET, I963, I956); quality of the plants eaten (MARTINET and MEUNIER, I959) and stock-raising temperature (DAKETSE, I977). These factors may affect food requirements and efficiency. In rat, food intake increases proportionally to temperature drop and depends on the composition of the food (BROBECK, I960). In sparrow, appetite increase in response to the lengthening days triggers the gonads (VAUGrEN, I96r). These observations led us to study the effect of temperature, daylight ratio and quality of the alfalfa eaten on food intake and on nitrogen and energy balance in field-vole. 


\section{MATERIAL AND METHODS}

\section{Animals}

From the day of birth, the cages containing the mothers and their pups were separated into different experimental groups. The female was taken from the cage at $2 \mathrm{I}$ days. The pups were thus weaned, but could stay in the nest up to one month, when they were isolated in individual cages.

At 30 days, males were put into individual cages with wire-netting floors for recovery of the uneaten alfalfa. Every morning from day 30 to 40 , the alfalfa distributed and the rejects from the day before were weighed. At day 40 , the animals were put into metabolism cages so that feces and urine could be recovered for 4 successive days.

The animals were weighed at day 30 before the beginning of the experiment, at day 40 before being put into metabolism cages and at the end of the experiment on day 45 .

\section{Techniques used}

Feces were weighed after dehydration for 30 minutes at $80^{3} \mathrm{C}$. The amount of nitrogen found in the alfalfa, feces and urine was determined by Kjeldahl's method. The energy value of alfalfa and feces was measured in a calorimetric bomb. As estimated by HLuszko et al. (I969), urine energy potential was calculated using Alwater's coefficient, $\mathrm{C}=7.9$ kcal per gram of urine nitrogen.

\section{Experimental groups}

Eight groups of animals were constituted according to a $2 \times 2 \times 2$ experimental design and raised under the following environmental conditions :

- two temperatures : $5^{\circ}$ or $22^{\circ} \mathrm{C}$.

During the experiment, temperatures varied in the first case between $3^{\circ}$ and $9^{\circ}$, in the second case between $20^{\circ}$ and $25^{\circ} \mathrm{C}$;

- two diets : Spring or fall alfalfa.

The alfalfa was cut, either at an early stage of growth $(30 \mathrm{~cm})$ during the first vegetative cycle in April (spring alfalfa), or at a later growth stage (6o $\mathrm{cm}$ or preflowering) during

TABLE I

Nitrogen, cellulose and energy levels of alfalfa havested at an early growth stage in the spring or at a late stage in the fall

\begin{tabular}{c|c|c|c}
\hline \multirow{2}{*}{ Alfalfa } & \multicolumn{2}{|c|}{ In \% dry matter } & $\begin{array}{c}\text { Calorific value } \\
\text { (cal./g) }\end{array}$ \\
\cline { 2 - 3 } & Nitrogen & Cellulose* & \\
\hline Dehydrated & & & \\
spring, 1971 & 3.7 & 16.0 & 4,060 \\
Fall, 1971 & 3.3 & 16.0 & 4,070 \\
\hline Frozen & & & - \\
spring, 1968 & 4.5 & 16.1 & - \\
Fall, 1968 & 3.5 & 24.0 & \\
\end{tabular}

* Cellulose was determined by the Laboratoire d'Essai et d'Analyses des Aliments, I.N.R.A. 
the fourth vegetation cycle in October (fall alfalfa). The alfalfa was ground and dried just after harvesting and stored in pellets. It was fed daily ad libitum.

The nitrogen, cellulose and energy content of spring and fall alfalfa is given in table r. Spring alfalfa is slightly richer in nitrogen than fall alfalfa. On the other hand, cellulose and energy content are the same in both alfalfas. These results are different than those obtained on stored frozen alfalfa, harvested in 1968 at the same growth stages and used in a previous experiment (MARTINET and MEUNIER, I969) : nitrogen content was higher in spring alfalfa than in fall alfalfa; on the opposite cellulose level was higher in fall alfalfa ;

- two daylight ratios: $15 \mathrm{~h}$ or to $\mathrm{h}$ of light per $24 \mathrm{~h}$.

\section{Analysis of results}

There were 7 to ro animals in each group, and we had several data per animal, 8 to to for the first period from 30 to 40 days and 4 for the second period from $4 \mathrm{I}$ to 45 days. Since the means and variances of daily individual data for each parameter studied were homogeneous within a group, we concluded that all individuals reacted identically to a given treatment.

Results were analyzed, taking the mean value of successive measurements for each field-vole and calculating from these the mean and the standard error for animals in the same group.

\section{RESULTS}

\section{Body growth}

Field-voles are bigger at $3^{\circ}$ days when the temperature is $5^{\circ}$ than when it is $22^{\circ}$, if they are fed spring alfalfa. This difference is not observed in the groups fed fall alfalfa (text fig. I).

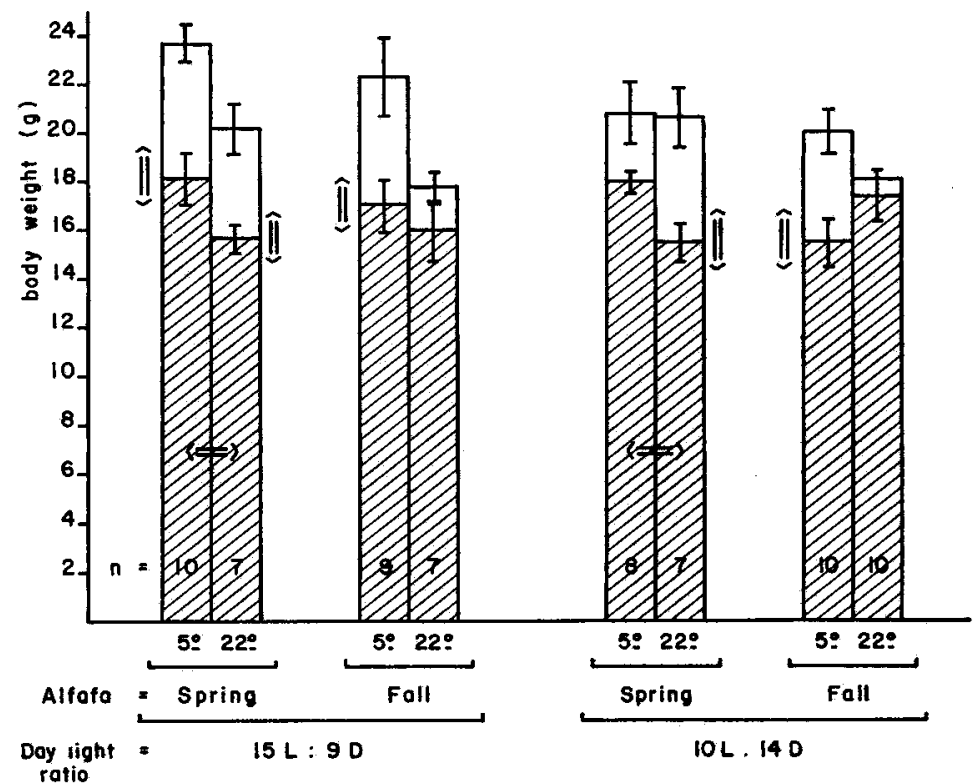

Fic. ז. - Body weight of field-voles raised under different conditions of temperature, feeding and daylight ratio

(hatching indicates weight at 30 days, white shows weight gain between day 30 and 40 ) $\leftrightarrow \mathrm{P}<0.05 \Leftrightarrow \mathrm{P}<0.0$ r between $22^{\circ}$ and $5^{\circ}$ at 30 days, $\uparrow \mathrm{P}<0.05 \uparrow \mathrm{P}<0.0 \mathrm{I}$ between 30 and 40 days. 
Weight gain between day 30 and 40 varies widely among animals. Some fieldvoles gained 7 grams in Io days, others less than I gram. Mean values range between 2.8 and $5.4 \mathrm{~g}$ in groups living at $5^{\circ}$, between 0.3 and $5.6 \mathrm{~g}$ in those living at $22^{\circ}$ (text fig. I).

From day 40 to 45 (when the animals were in metabolism cages), most fieldvoles lost weight ; loss reached $6 \mathrm{~g}$ in some cases. However, nitrogen and energy balance always remained positive. The low correlation between weight gain and amount of food eaten or assimilated may be explained by the irritability of animals which adapted poorly to cages with a wire-netting floor and no shelter (table 2).

TABLE 2

Relation between liveweight gain and efficiency of food conversion

\begin{tabular}{|c|c|c|c|}
\hline \multirow{2}{*}{ Temperature } & \multirow{2}{*}{$\begin{array}{l}\text { Weight gain in mg } \\
\text { per } g \text { of alfalfa eaten }\end{array}$} & \multicolumn{2}{|c|}{$\begin{array}{l}\text { Correlation between weight gain } \\
\text { and food intake }\end{array}$} \\
\hline & & $\begin{array}{c}\text { From } 30 \text { to } \\
40 \text { days }\end{array}$ & $\begin{array}{l}\text { From } 40 \text { to } \\
45 \text { days }\end{array}$ \\
\hline $\begin{array}{r}5^{\circ} \\
22^{\circ}\end{array}$ & $\begin{array}{l}32 \\
11\end{array}$ & $\begin{array}{l}y=0.36^{*} \\
y=0.42^{*}\end{array}$ & $\begin{array}{l}r=0.11 \\
r=0.01\end{array}$ \\
\hline$* \mathrm{P}<0,01$ & & & \\
\hline
\end{tabular}

\section{Food and dry matter intake}

Results on intake for the two periods ( $30-40$ days and $4 \mathrm{I}$ to 45 days) were regrouped because there was no difference between them. Daily alfalfa intake par animal was always higher at $5^{\circ}$ than at $22^{\circ} \mathrm{C}(\mathrm{P}<0.0 \mathrm{r})$, whatever the quality of the alfalfa or the length of the daylight period. On the other hand, these latter two factors do not affect the quantities ingested (text fig. 2).

The difference observed between intake at $5^{\circ}$ and at $22^{\circ} \mathrm{C}$ is also found in the proportions of dry matter assimilated (weight of alfalfa ingested - feces dry weight), although conversion ratios are higher at $22^{\circ}$ than at $5^{\circ} \mathrm{C}$ (text fig. 2).

\section{Nitrogen intake and balance data}

The proportion of nitrogen ingested and assimilated (ingested nitrogen - fecal nitrogen) are always higher at $5^{\circ}$ than at $22^{\circ} \mathrm{C}(\mathrm{P}<0.0 \mathrm{r})$. However, nitrogen conversion ratios are higher at $22^{\circ} \mathrm{C}$ in animals fed fall alfalfa ; in those fed spring alfalfa, the ratios are the same at $5^{\circ}$ and $22^{\circ} \mathrm{C}$ (table 3 ). The final balance shows that metabolizable nitrogen (ingested nitrogen - urinary + fecal nitrogen) is higher at $5^{\circ}$ than at $22^{\circ}$ in animals raised under long ${ }^{15}$-hour daylight. However, under short Io-hour daylight, the proportion of metabolizable nitrogen per animal is the same at $5^{\circ}$ and $22^{\circ} \mathrm{C}$. 

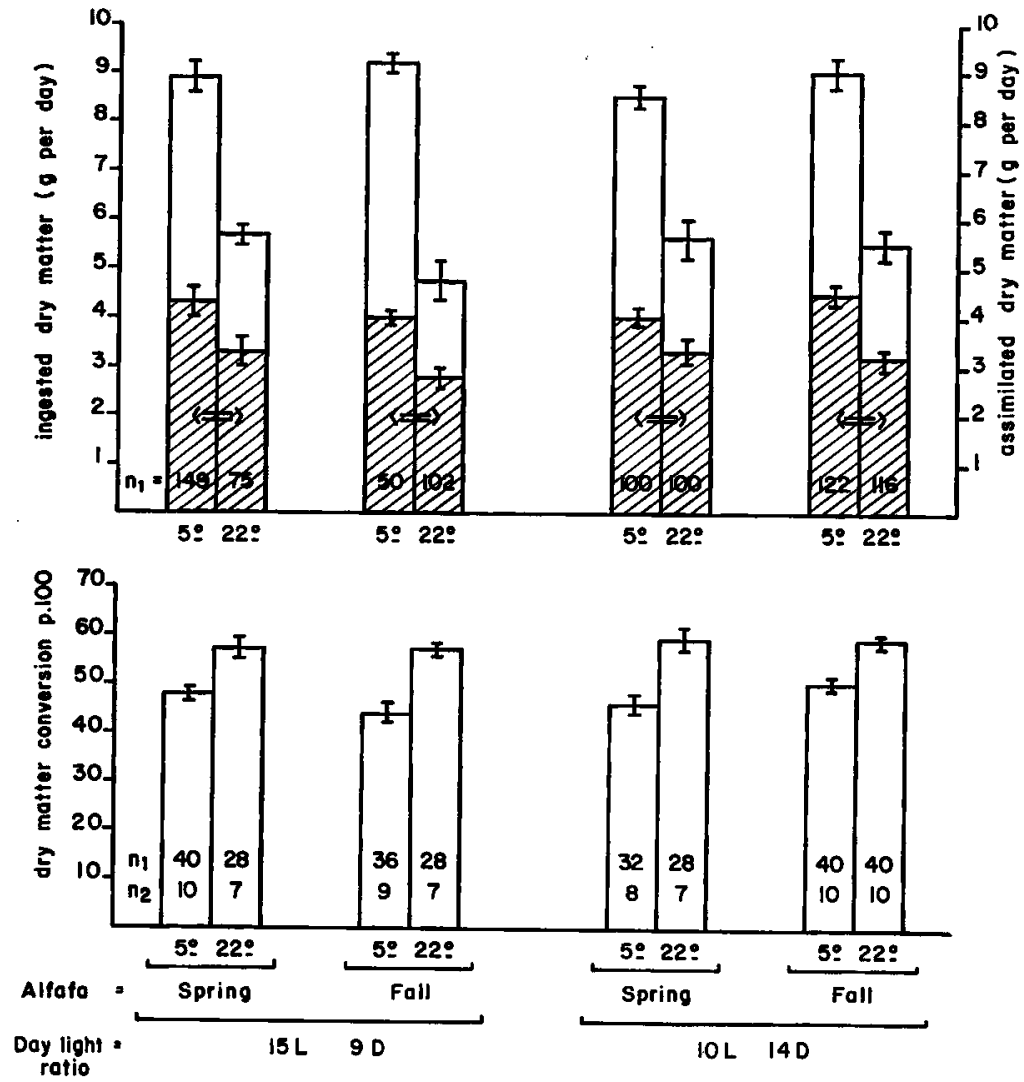

FrG. 2. - Variations in quantities of ingested and assimilated dry matter per male and conversion ratios correlated to temperature, daylight ratio and quality of the alfalfa eaten

$\Leftrightarrow P<0.01$ (white $=$ ingested dry matter, hatching $=$ assimilated dry matter)

$n_{1}=$ number of measurements $=$ number of days $\times$ number of animals

$n_{2}=$ number of animals

The interaction temperature - daylight ratio complicates interpretation of the results. Alfalfa quality does not seem to affect nitrogen balance.

\section{Energy intake and balance data}

Mean fecal energy value is about 4,000 calories per gram; the urinary value varies between $o$ and 400 calories per day, depending on urine volume. Results are the same as the preceding ones, $i . e$. the proportion of energy ingested and metabolized is much higher at $5^{\circ}$ than at $22^{\circ}$; alfalfa quality and daylight ratio have no effect (table 3).

\section{DISCUSSION}

There is little data in the literature on the food requirements and intake of the field-vole. The figures on daily intake of dry matter reported by DROzDz (I968) for Microtus arvalis agree with those cited here. Dry matter or nitrogen conversion ratios 
M. CAILI,OL, L. MARTINET

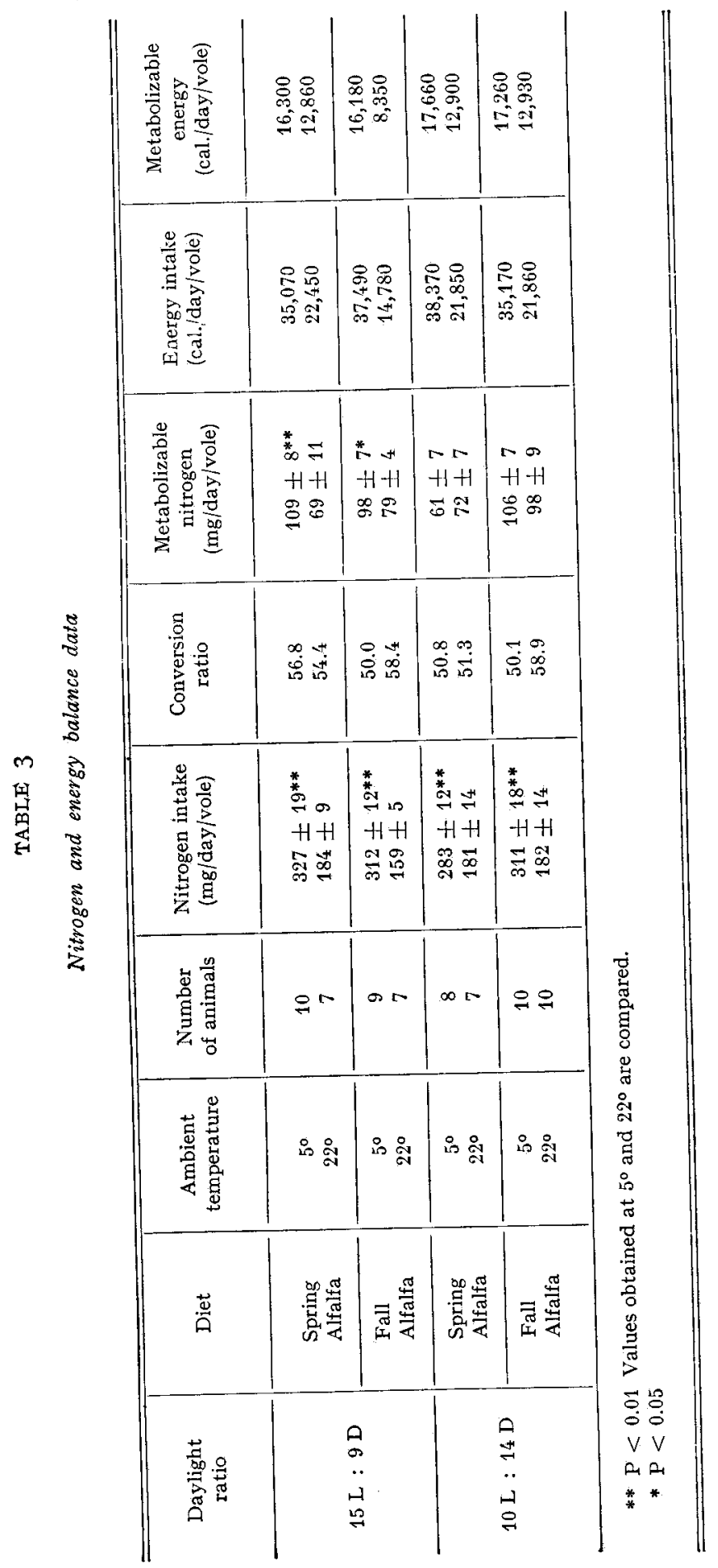


for Microtus pennsylvanicus (JoHANNINGSMEIER, I966 ; CowAN et al., I968) are also very similar to those found for Micro'us arvalis, but no details of the experimental conditions are given.

However, ambient temperature plays a considerable role in food intake; a field-vole eats almost two times more at $5^{\circ}$ than at $22^{\circ}$. This increase in energetic requirements and food intake is identical when the temperature decreases from $2 \mathrm{I}$ to $-3^{\circ}$ in mouse (BARNETT et $a^{\prime}$., I965), and from 25 to $4^{\circ} \mathrm{C}$ in hamster (BAUMAN et al., 1968$)$.

On the other hand, conversion ratios increase when the temperature rises, i.e when the amounts ingested drop. In spite of this, the nitrogen or energy intake remains higher at $5^{\circ}$ than at $22^{3}$. We do not know if the increased energy supply explains why animals living at $5^{3}$ grow a little faster; in fact, the cold stimulated growth in field-vole (DAKETSE, I977), contrary to mouse in which growth is retarded in spite of increased food intake (BARNETT and NEIL, I97I).

Increased appetite in Peromyscus leucopus (LYNch, I972) or in sparrow (VAUGIEN, I96I) due to lengthening days does not occur in the field-vole. However, I5 hours of daylight per day has a favorable effect on the amount of metabolizable nitrogen available to the field-vole; body growth is faster in long days than in short days in Microtus arvalis (MARTINET and MeUnier, I969; MARTINET and SpITZ, I970). AGUILERA et al. (1969) also observed the favorable effect of lenghtening daylight on protein conversion in rabbit.

No effect of alfalfa quality has been shown in this study. However, body growth rate is faster with alfalfa harvested at an early growth stage in the spring than with alfalfa harvested at a later growth stage in the fall (MARTINET and MEUNIER, I969). As in another field-vole, Microtus pennsylvanicus (REYS et al., 1970), or in rabbit (HOOVER and HEITMANN, 1972), the higher cellulose content in alfalfa harvested at a late growth stage in the fall may cause a decrease of the dry matter conversion ratio.

Unfortunately, nitrogen levels in both alfalfas used were similar and cellulose and energy levels identical. This unexpected results is quite different from those obtained by us (table I) or by JoYCE and BRUNSwICk (I975) on stored frozen alfalfas.

Reçu pour publication en avril 1976.

\section{RÉSUMÉ}

\section{EFFET DE LA TEMPÉRATURE}

SUR IA CONSOMMATION DE NOURRITURE, D'AZOTE ET D'ÉNERGIE CHEZ LE CAMPAGNOL, DES CHAMPS MICROTUS ARVALIS EN FONCTION DE I,A DURÉE QUOTIDIENNE D'ÉCLAIREMENT E'T DE, L,A QUALITÉ DE L'ALIMENT

La consommation alimentaire, les bilans énergétiques et azotés ont été mesurés chez le Campagnol en fonction de la température d'élevage, de la durée quotidienne d'éclairement ou du stade végétatif et de la date de récolte de la luzerne consommée.

Le froid augmente la consommation de nourriture, bien que les coefficients da digestibilité de la matière sèche et de l'azote soient supérieurs à $2^{\circ}$; les quantités d'azote et d'énergie assimilées sont plus élevées à $5^{\circ}$. 
La durée d'éclairement ne modifie pas la consommation alimentaire ; on observe cependant une augmentation de l'azote métabolizable par l'animal lorsqu'il vit sous une photopériode claire quotidienne longue.

Le rôle du stade de croissance de la luzerne utilisée comme aliment et de la date de la récolte n'a pu être élucidé à cause de la méthode de conservation utilisée.

\section{REFERENCES}

Aguilera J., Boza J., Fonolla J., Varela G., I969. Effect of period of illumination on the nutritive return from a diet for rabbits. Rev. Nutricion animal Madrid, 7, 27-38.

Barnett S. A., Little M. J., I965. Maternal performance in mice at $-3^{\circ} \mathrm{C}$. Food consumption and fertility. Proc. Roy. Soc. Ser. B, 162, 492-5or.

BarnetT S. A., Neil A. C., I97I. Growth and reproduction of mice reared at different temperatures. J. Physiol., 215, 665-678.

Bauman T. R., Anderson R. R., Turner C. W., I968. Thyroid hormone secretion rates and food consumption of the hamster (Mesocricetus auratus) at $25,5^{\circ} \mathrm{C}$ and $4,5^{\circ} \mathrm{C}$. Gen. Comp. Endocr., 10, $92-98$.

Brobeck J. R., I960. Food and temperature. Rec. Prog. Horm. Res, 16, 439-466.

Cowan R. L., Long T. A., Jarrett M., 1968. Digestive capacity of the meadow vole (Microtus pennsylvanicus). J. Anim. Sci., 27, 1517 (abstr.).

Daketse M. J., r977. Influence de la température sur la croissance et la fertilité du Campagnol des champs, Microtus arvalis, élevé sous différentes conditions de photopériode et d'alimentation. Ann. Biol. anim. Biophys. Biochim., (à parâ̂tre).

Drozdz A., I968. Digestibility and assimilation of natural food in small rodents. Acta. Theriol., 13, $367-389$.

Hluszko M. T., Porter R., Chevillard L., rg69. Bilan énergétique chez les rats adaptés à $5^{\circ}$ ou à $3^{\circ}$ et soumis à des régimes contenant 5 p. Ioo ou 30 p. roo de lipides. C. R. Soc. Biol, , 163, 344-348.

Hoover W. H., Heitmans R. N., I 972 . Effects of dietary fiber levels on weight gain, cecal volume and volatile fatty acid production in rabbits. $J$. Nutr., 102, 375-380.

Johanningsmeier A. G., 1966. Studies on energy and material utilization in Microtus pennsylvanicus under field and laboratory conditions. Ph. D. Am. Thesis, Purdue University, $264 \mathrm{pp}$.

Joyce J.-P., Brunswick L., Parkes J., r972. Feeding value of lucerne. Proc. N. Z. Soc. Anim. Prod., 32, 54-63.

Keys J. E., VAn Soest P. J., I970. Digestibility of forages by the meadow vole (Microtus pennsylvanicus). 'J. Dairy Sci., 53, I502-1508.

LECYK M., I962. The effect of the length of daylight on reproduction in the field-vole (Microtus arvalis). Zool. Pol., 12, I89-22I.

LECYK M., I963. The effect of short daylight on sexual maturation in young individuals of the fieldvole, Microtus arvalis. Zool. Pol., 13, 77-86.

LYNCH G. R., I972. Effect of temperature and photoperiod on physiological and behavioral thermoregulation in the white-footed mouse, Peromyscus Leucopus. Ph. D. Am. Thesis, Iowa University, $109 \mathrm{pp}$.

Martiner L., 1963. Établissement de la spermatogenèse chez le Campagnol des champs (Microtus arvalis) en fonction de la durée quotidienne d'éclairement. Ann. Biol. anim. Biochim. Biophys., 3, 343352.

Martinet L., 1966. Modification de la spermatogenèse chez le Campagnol des champs (Microtus arvalis) en fonction de la durée quotidienne d'éclairement. Ann. Biol. anim. Biochim. Biophys., 6, 30r-313.

Martinet L., Meunier M., I969. Influence des variations saisonnières de la Iuzerne sur la croissance, la mortalité et l'établissement de la maturité sexuelle chez le Campagnol des champs (Microtus arvalis). Ann. Biol. anim. Biochim. Biophys., 9, 45I-462.

Martinet L., Spitz F., rg7I. Variations saisonnières de la croissance et de la mortalité du Campagnol des champs, Microtus arvalis : rôle du photopériodisme et de la végétation sur ces variations. Mammalia, 35, $38-84$.

Vaugien L., r96r. L'appétit du moineau domestique dépend de la durée des jours et de son état sexuel. Implication avec le cycle reproducteur. C. $R$. Acad. Sci., 252, 2448-2450. 